\title{
STRATEGI BERSAING RUMAH MAKAN HENI PUTRI KAILI
}

\author{
RAYMONDO WENGKAU \\ CHALIL \\ MASKURI \\ Jurusan Manajemen, Fakultas Ekonomi, Universitas Tadulako
}

\begin{abstract}
Heni Putri Kaili Restaurant is located at Kaombona Street/ Kampung Nelayan No. 09 Talise, East Palu Sub-district, Palu City. Heni Putri Kaili restaurant has been established since 6 years ago, precisely on February 20th 2010. The owner of the restaurant is Mrs. Haeni R. Kara, S.Pd. The research intends to find out the competitive level faced by Heni Putri Kaili Restaurant among the restaurant industries in Palu City and to comprehend the alternative strategy that can be used by Heni Putri Kaili Restaurant. Data analysis methods used are Porter's Five Forces analysis and the SWOT (Strength, Weakness, Opportunities, Threats) analysis. Based on Porter's Five Forces analysis, the study concludes that Heni Putri Kaili restaurant experiences a great rivalry among the restaurant industries in Palu City, which includes the rivalry beetween the competitors from the similiar industry, the suplier's supplying capacity, and the threat of substitutes products. The result of SWOT metric diagram and IE table suggests that Heni Putri Kaili Restaurant should focus on the diversifications strategy while improving the service and the strategy to increase the promotion of the main product together with other products that are still unfamiliar by the consumers/markets.
\end{abstract}

Keywords: competitive strategy, restaurant, porter's five forces, SWOT

\begin{abstract}
Abstrak
Heni Putri Kaili Restaurant terletak di Kampung Nelayan No. 09 Talise, Kecamatan Palu Timur, Kota Palu. Restoran Heni Putri Kaili telah berdiri sejak 6 tahun yang lalu, tepatnya pada 20 Februari 2010. Pemilik restoran tersebut adalah Nyonya Haeni R. Kara, S.Pd. Tujuan penelitian ini adalah untuk mengetahui kondisi persaingan restoran Heni Putri Kaili di antara industri restoran di Kota Palu dan untuk mengetahui strategi alternatif yang dapat digunakan oleh restoran Heni Putri Kaili. Metode analisis data yang digunakan adalah analisis Lima Kekuatan Porter dan SWOT (Strength, Weakness, Opportunities, Threats). Berdasarkan analisis Lima Kekuatan Porter, dapat disimpulkan bahwa persaingan antara restoran Heni Putri Kaili di industri restoran di Kota Palu mengalami persaingan yang sangat baik. Ada banyak faktor; persaingan antara pesaing dari industri serupa, kapasitas penyuplai suplier, dan ancaman produk substitusi. Sebagai hasil diagram metrik SWOT dan tabel IE, strategi kompetitif dapat direkomendasikan. Restoran Heni Putri Kaili berfokus pada Strategi Diversifikasi dengan program strategi untuk menegakkan dan memperbaiki layanan dan strategi untuk meningkatkan promosi produk unggulan tanpa meninggalkan produk lain yang masih belum diketahui oleh konsumen / pasar.
\end{abstract}

Kata Kunci: Strategi Kompetitif, Restoran, Lima Kekuatan Porter, SWOT

\section{PENDAHULUAN}

\section{Latar Belakang Penelitian}

Seiring dengan perubahan zaman, kecenderungan orang untuk makan di luar rumah semakin meningkat dengan berbagai alasan praktis, ekonomis maupun prestige. Konsep yang ditawarkan kepada konsumen berbeda-beda mulai dari konsep hidangan cepat saji yang ditujukan bagi mereka yang sibuk dan punya waktu sedikit saja untuk makan dan saat ini konsep tersebut meluas dengan semaraknya bisnis kuliner yang menawarkan tempat makan yang nyaman.

Sejalan dengan semaraknya bisnis kuliner, berkembang pula perilaku pembelian konsumen. Perubahan perilaku pembelian yang awalnya tidak terlalu kritis dimana hanya harga yang menjadi patokan pembelian sedangkan faktor lain cenderung diabaikan, kini perilaku pembelian konsumen tersebut 
berubah menjadi sangat selektif dan kritis dalam menentukan pilihan pembelian. Bukan hanya dari rasa makanan, tetapi juga terdapat berbagai faktor lain yang pada saat ini mempengaruhi keputusan pembelian konsumen seperti suasana tempat, fasilitas tempat, hiburan dan dari segi pelayanan yang ada di restoran tersebut. Keadaan ini merupakan peluang tersendiri bagi bisnis dibidang kuliner.

Selama tiga tahun terakhir ini di Kota Palu Provinsi Sulawesi Tengah mengalami peningkatan pertumbuhan penduduk. Menurut Badan Pusat Statistik Kota Palu, jumlah penduduk Kota Palu pada tahun 2013 mencapai 356,3 ribu jiwa, meningkat sebesar 1,66\% pada tahun 2014 mencapai 362,2 ribu jiwa dan pada akhir tahun 2015 penduduk Kota Palu mencapai 368,6 ribu jiwa meningkat 1,77\% dari tahun sebelumnya.

Jika dicermati maka jumlah penduduk kota Palu yang terus bertambah dari tahun ketahun dapat menjadi peluang pasar bagi bisnis kuliner. Potensi pasar yang terus berkembang memacu para pebisnis bersaing untuk menawarkan konsep yang berbeda dari para pesaingnya.

Disisi lain dengan semakin berkembangnya bisnis rumah makan menimbulkan persaingan yang ketat antar pelaku usaha. Para pelaku usaha berlomba-lomba memberikan yang terbaik kepada konsumen, sehingga para pelaku usaha rumah makan harus memikirkan strategi yang tepat untuk menjaga kelangsungan usahanya.

Jika dilihat dari perkembangan warung/kedai makan dan rumah makan/restoran di kota Palu, selama tiga tahun terakhir juga mengalami peningkatan, pertumbuhan tersebut dapat dilihat pada Tabel 1 .

Tabel 1. Pertumbuhan Warung/Kedai Makan dan

Rumah Makan/Restorandi Kota Palu Tahun 2013-2015

\begin{tabular}{lccccc}
\hline No. Tahun & $\begin{array}{c}\text { Warung/ } \\
\text { Kedai } \\
\text { Makan }\end{array}$ & $\begin{array}{c}\text { Pertumbuhan } \\
\mathbf{( \% )}\end{array}$ & $\begin{array}{c}\text { Rumah } \\
\text { Makan// } \\
\text { Restoran }\end{array}$ & $\begin{array}{c}\text { Pertumbuhan } \\
\mathbf{( \% )}\end{array}$ \\
\hline 1 & 2013 & 873 & 2,70 & 35 & 20,6 \\
2 & 2014 & 903 & 3,43 & 54 & 54,2 \\
3 & 2015 & 979 & 8,41 & 85 & 57,4 \\
\hline
\end{tabular}

\section{Sumber : Badan Pusat Statistik Kota Palu 2015}

Setelah dilihat dari pertumbuhan penduduk di kota Palu pada Tabel 1 tidak sebanding dengan laju pertumbuhan warung/kedai makan dan rumah makan/restoran di kota Palu, dari fenomena tersebut dapat disimpulkan bahwa perkembangan tersebut mendorong para pengusaha industri kuliner di kota Palu untuk bersaing dan berlomba-lomba merebut pangsa pasar serta dituntut untuk mencari kiat-kiat yang tepat agar tetap mampu bertahan menghadapi persaingan.

RM. Heni Putri Kaili yang berada di Jl. Kaombona/ Kampung Nelayan No. 09 Talise, Kecamatan Palu Timur, Kota Palu, merupakan rumah makan Kaili yang menyediakan aneka hidangan asli dari Tanah Kaili. Konsep Rumah Makan Heni Putri Kaili didesain langsung oleh pemilik, mengambil tempat tepat di pinggir Pantai Talise menjadikan RM. Heni Putri Kaili banyak dilirik oleh pengunjung baik dari dalam maupun luar kota Palu. Mulai dari kalangan pejabat pemerintahan dan orang-orang penting di kota Palu sampai kalangan artis pun selalu ramai menikmati makanan di rumah makan khas Kaili ini. Harga yang ditawarkan beraneka ragam dan pastinya menu-menu yang ditawarkan sangat menggugah selera pengunjung. Salah satu keunikan RM. Heni Putri Kaili adalah setiap pengunjung akan disambut Si Putri Kaili dengan menggunakan baju adat khas Tanah Kaili.

Dalam situasi persaingan serta tantangan karena perubahan situasi yang terus menerus, peningkatan eksistensi maupun produktifitas tentu diinginkan oleh setiap perusahaan maupun pengusaha, tidak terkecuali Rumah Makan Heni Putri Kaili peningkatan eksistensi maupun produktifitas diharapkan dapat meningkatkan margin keuntungan secara signifikan.

Berdasarkan fenomena di atas, penulis tertarik untuk melakukan penelitian dengan judul "Strategi Bersaing Rumah Makan Heni Putri Kaili".

\section{Tujuan Penelitian}

Berdasarkan latar belakang masalah dan rumusan masalah yang telah dijabarkan diatas maka penelitian ini bertujuan sebagai berikut: 
1. Mengetahui kondisi persaingan Rumah Makan Heni Putri Kaili pada industri rumah makan di Kota Palu

2. Mengetahui strategi bersaing Rumah Makan Heni Putri Kaili.

\section{KAJIAN LITERATUR DAN PENGEMBANGAN HIPOTESIS Pengertian Strategi Bersaing}

Menurut Freddy Rangkuti (2004), Keberhasilan suatu strategi yang telah ditetapkan sangat ditentukan oleh seberapa besar tingkat kesesuaian strategi tersebut dengan perubahan lingkungan, pesaing, serta situasi organisasi faktor-faktor dalam merumuskan strategi dalam kondisi posisi persaingan yang kuat dan membanggun kekuatan kompetitif.

Keunggulan kompetitif adalah strategi bersaing terhadap sesuatu yang dirancang untuk dieksploitasi oleh suatu organisasi. Selanjutnya bagaimana cara organisasi untuk mendapatkan keunggulan kompetitif yang berkelanjutan merupakan inti dari strategi bersaing. Pilihan strategi bersaing didasarkan pada keunggulan kompetitif yang dapat dikembangkan oleh organisasi. Bagaimana cara unit bisnis atau organisasi akan bersaing dalam suatu industri adalah pilihan dari strategi bersaing.

Keunggulan bersaing yang berkesinambungan terjadi pada saat perusahaan menerapkan suatu strategi pencipta nilai dan perusahaan pesaing tidak secara berkesinambungan menerapkannya, serta saat perusahaan lain tidak mampu meniru keunggulan bersaing tersebut. Kemudian Rangkuti mengemukakan bahwa keunggulan bersaing disebabkan oleh pilihan strategi yang dilakukan perusahaan untuk merebut peluang pasar. Strategi bersaing berfokus pada peningkatan posisi bersaing produk dan jasa perusahaan dalam industri atau segmen pasar tertentu yang dilayani perusahaan. Daya saing strategis (strategic competitiveness) dicapai apabila sebuah perusahaan dengan baik merumuskan serta menerapkan strategi pencipta nilai.

\section{Pengertian Porters's Five Forces}

Menurut Porter (2006), ada lima (5) kekuatan (forces) persaingan yang membentuk strategi. Model lima kekuatan Michael Porter adalah model yang digunakan untuk melakukan analisis industri dan analisis keunggulan kompetitif. Memahami kekuatan yang membentuk persaingan di industry adalah titik awal dalam pengembangan strategi. Kekuatan tersebut akan menunjukkan aspek-aspek yang paling signifikan dari lingkungan persaingan. Kekuatan tersebut juga akan menunjukkan apakah suatu industri benar-benar menarik, dan juga membantu investor untuk mengantisipasi sisi positif dan negatif dalam struktur industri. Lima kekuatan tersebut adalah ancaman pendatang baru, posisi tawar konsumen, posisi tawar pemasok, ancaman produk/jasa substitusi dan persaingan dalam industri. Untuk menyusun rancangan strategi yang baik dan agar dapat menduduki posisi yang kompetitif dalam industrinya maka perusahaan harus dapat meminimumkan dampak kelima kekuatan tersebut.

\section{Pengertian SWOT}

Metode Analisis SWOT dianggap sebagai metode analisis yang paling dasar, berguna untuk melihat suatu topik atau permasalahan dari 4 (empat) sisi yang berbeda. Hasil Analisis biasanya adalah arahan atau rekomendasi untuk mempertahankan kekuatan dan menambah keuntungan dari peluang yang ada, sambil mengurangi kekurangan dan menghindari ancaman. Jika digunakan dengan benar, analisis SWOT akan membantu kita untuk melihat sisi- sisi yang terlupakan atau tidak terlihat selama ini.

Proses pengambilan keputusan strategis selalu berkaitan dengan pengembangan misi, tujuan, strategi dan kebijakan perusahaan. Dengan demikian perencana strategis (strategic planner) harus menganalisis faktor-faktor strategis perusahaan (kekuatan, kelemahan, peluang dan ancaman) dalam kondisi yang ada saat ini. Hal ini disebut analisis situasi dan model yang paling popular untuk analisis situasi adalah analisis SWOT.

Analisis SWOT membandingkan antara faktor eksternal peluang dan ancaman dengan faktor internal kekuatan dan kelemahan. Menurut Pearce \& Junior (2014), gambar tersebut mengilustrasikan bagaimana analisis SWOT dapat mengarahkan diskusi perencanaan manejerial menjadi pendekatan yang lebih terstruktur untuk membantu analisis strategi. Tujuannya adalah mengidentifikasi salah satu dari empat pola unik dalam memasangkan sumber daya internal perusahaan dengan situasi eksternal. 


\section{METODE PENELITIAN}

\section{Teknik Pengumpulan Data}

Dalam melakukan penelitian ini, Peneliti menggunakan beberapa teknik pengumpulan data, yaitu:

1. Penelitian pustaka (library research), Melalui penelitian pustaka penulis juga mengumpulkan sumber informasi dari para ahli yang bersifat teoritis dan berhubungan dengan penelitian ini.

2. Penelitian lapang (field research), yaitu dengan cara:

a. Observasi

Observasi yang didalamnya peneliti langsung turun ke lapangan untuk mengamati kondisi RM. Heni Putri Kaili.

b. Wawancara

Wawancara adalah usaha untuk mengumpulkan data dengan melakukan wawancara berkaitan dengan visi dan misi Rumah Makan Heni Putri Kaili. Narasumber yang dipilih dalam penelitian ini yaitu sebanyak 2 (dua) orang terdiri dari 1 (satu) orang pemilik RM. Heni Putri Kaili dan 1 (satu) orang Menejer RM. Heni Putri Kaili.

c. Kuesioner

Kuesioner adalah pengumpulan data yang digunakan dengan cara membuat dan menyebarkan daftar penilaian dari pernyataan-pernyataan yang telah diajuakan kepada narasumber. $d$. Dokumentasi

Dokumentasi adalah teknik mengumpulkan data melalui bahan-bahan tertulis berupa struktur organisasi, serta dokumen-dokumen tentang pendapat dan teori yang berhubungan dengan masalah penelitian.

\section{Tahapan Analisis Data}

Seperti dikemukakan oleh Sarwono (2006:257), bahwa dalam tradisi riset dikenal ada dua jenis pendekatan utama penelitian, yaitu pendekatan kuantitatif dan kualitatif. Pendekatan kuantitatif menekankan pada penggunaan angka-angka, rumus-rumus statistik serta pengukuran, sementara pendekatan kualitatif memfokuskan pada aspek kealamiahan data.

Penelitian ini menggunakan metode kualitatif, dikarenakan bertujuan untuk menganalisis strategi bersaing untuk meningkatkan penjualan dan pengembangan usaha yang sebaiknya digunakan RM. Heni Putri Kaili berdasarkan teori analisis Porter's Five Forces dan analisis SWOT.

Seperti ditulis oleh Robert K. Yin (1999:5), bahwa dalam penelitian dengan menggunakan metode studi kasus, maka pertanyaan penelitian harus menjawab pertanyaan "How (bagaimana)" dan "Why (mengapa)", seperti tampak pada Tabel di bawah ini.

Tabel 2. Pertanyaan Penelitian Strategi dengan Metode Kasus

\begin{tabular}{cccc}
\hline Strategy & $\begin{array}{c}\text { Form of research } \\
\text { Question }\end{array}$ & $\begin{array}{c}\text { Requires control } \\
\text { over behavioral } \\
\text { events? }\end{array}$ & $\begin{array}{c}\text { Focuses on } \\
\text { contemporar } \\
\text { events? }\end{array}$ \\
\hline Experiment & How, why & Yes & Yes \\
Survey & $\begin{array}{c}\text { Who, What, } \\
\text { Where, How } \\
\text { Many, How much } \\
\text { Who, What, }\end{array}$ & No & Yes \\
Archival & $\begin{array}{c}\text { Where, How } \\
\text { Analysis } \\
\text { many, how much }\end{array}$ & No & Yes/No \\
History & How, Why & No & No \\
Case Study & How, Why & No & Yes \\
\hline
\end{tabular}

Sumber: Robert K. Yin, Case Study Research, (1999:6 ) 
Dengan demikian, dalam penelitian ini pertanyaan penelitian yang mencakup pertanyaan How dan Why, adalah tentang bagaimana strategi bersaing untuk meningkatkan penjualan dan pengembangan usaha yang sebaiknya digunakan RM. Heni Putri Kaili berdasarkan analisis

Porter's Five Forces dan analisis SWOT serta alasan-alasan yang mendasari hal tersebut.

Berikut ini adalah teknik analisis data yang dilakukan dalam penelitian ini antara lain adalah:

1. Mengumpulkan data dan informasi yang diperoleh melalui wawancara serta kuesioner.

2. Hasil pengamatan dan studi literatur kemudian dihubungkan dengan pokok masalah penelitan, juga faktor-faktor pendukung atau penghambat yang memberikan pengaruh pada hasil penelitian.

3. Selanjutnya dilakukan analisa masalah dengan menggunakan metode-metode analisa seperti yang telah dikemukakan pada bahasan sebelumnya yaitu Analisi Porter's Five Forces dan Analisis SWOT, dalam hal ini melakukan analisa kondisi perusahan dalam rangka penentuan strategi bisnis yang tepat sesuai dengan kebutuhan.

4. Hasil dari pemodelan dan analisa akan merupakan kesimpulan dari penelitan ini, dan berdasarkan itu juga akan diberikan rekomendasi-rekomendasi strategis bagi RM. Heni Putri kaili.

Analisis Porter's Five Forces Model Analisis Porter's Five Forces Pendefinisian peran dalam model Analisis Porter's Five Forces pada Rumah Makan Heni Putri Kaili dijabarkan sebagai berikut:

1. Pendatang baru didefinisikan sebagai pemain baru yang akan hadir dalam persaingan antar sesama rumah makan.

2. Pembeli dalam rumah makan adalah konsumen RM. Heni Putri Kaili

3. Pemasok dalam rumah makan adalah pemasok kebutuhan bahan baku RM. Heni Putri Kaili

4. Produk pengganti dalam rumah makan ini adalah seluruh warung makan di Kota Palu 5. Pesaing dalam rumah makan ini adalah seluruh rumah makan di Kota Palu

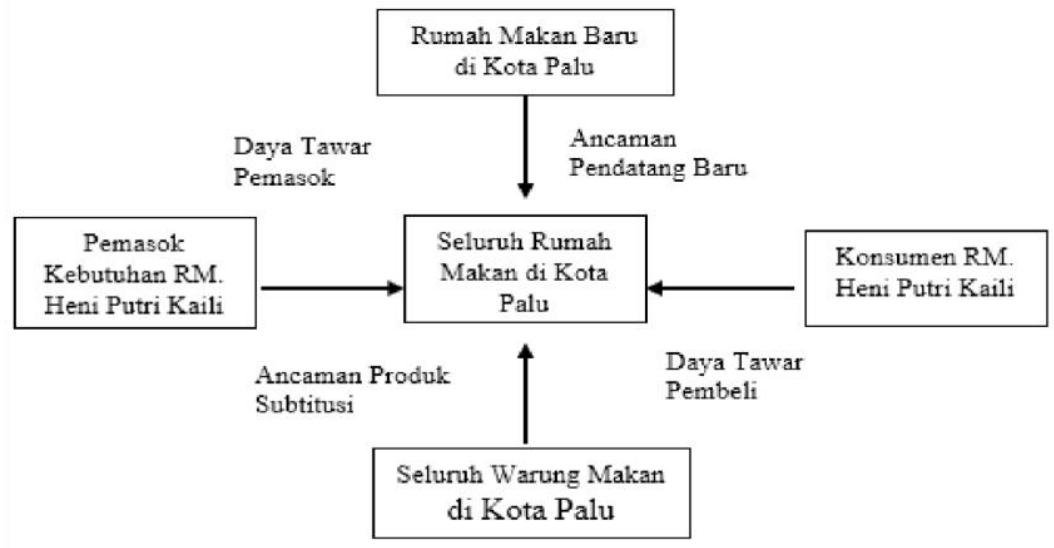

Gambar 1. Indentifikasi Pemain dalam Industri

\section{Metode Penilaian Porter's Five Forces}

Setelah melakukan identifikasi terhadap tiap-tiap komponen, kemudian dilakukan pemodelan dan perhitungan berdasarkan variabel-variabel dengan menggunakan asumsi pembobotan untuk menganalisis indikator dari masing-masing variabel yang telah ditentukan. Adapun penilaian yang akan digunakan untuk membantu menganalisa adalah dilakukan dengan cara-cara sebagai berikut:

1. Menetapkan parameter yang sesuai dengan kondisi lingkungan eksternal industri. Isi dari parameter ialah variabel dengan indikator variabel yang sesuai dengan keadaan industri saat ini.

2. Pemberian bobot pada tiap-tiap faktor sesuai dengan kepentingan daripada pengaruh faktor tersebut, pembobotan dinilai dari angka 0,0 (tidak penting) hingga angka 1 (sangat penting). Pemberian bobot merupakan dimaksudkan untuk memberikan dampak terhadap faktor strategik. Pemberian bobot yang wajar dapat ditentukan dengan mendiskusikan faktor yang terkait. Jumlah bobot yang diberikan pada setiap faktor harus sama dengan 1 .

3. Pemberian peringkat atau rangking dari nilai 1 hingga nilai 9 kepada masing-masing variabel didasarkan kepada kondisi eksteral pada industri saat ini yang mempengaruhi bisnis secara langsung maupun tidak langsung. Cara penilaian ini adalah nilai 1 untuk sangat tidak berkatian hingga nilai 9 untuk yang sangat berkaitan sekali. 
4. Kalikan bobot dengan rangking untuk memperoleh nilai dari faktor-faktor tersebut, Dari nilai tersebut nantinya akan dipergunakan untuk memperoleh posisi industri terhadap lingkungan eksternal.

5. Untuk pembobotan dilakukan persentase rata-rata indikator yang sesuai yaitu yang memiliki nilai 1 terhadap keseluruhan jumlah indikator dalam suati tekanan, maka tekanan akan diberi penilaian sebagai berikut:

Rendah : apabila nilai antara $0-3$

Sedang : apabila nilai antara $3,1-6$

Tinggi : apabila nilai antara $6,1-9$

\section{Model Tabel Analisis Porter's Five Forces}

Menurut Pearce dan Robinson (2014 : 105), para pembuat strategi, yang menginginkan perusahaannya berada pada posisi teratas dalam mengatasi lingkungan industri atau mempengaruhi lingkungan tersebut sedemikian rupa sehingga menguntungkan perusahaan, harus belajar mengenal hal-hal yang membuat lingkungan kerja. Dalam menentukan strategi diperlukan analisis untuk mendapatkan gambaran dan bukti-bukti dari hasil analisa tersebut, bukti-bukti tersebut bisa berupa data, ataupun dari berbagai sumber yang telah tervalidasi, prediksi dan asumsi. Oleh karena itu dilakukan analisa lingkungan eksternal industri dengan menggunakan analisa Porter's five forces yang sudah dijelaskan pada bab sebelumnya. Berikut ini tabel berdasarkan variabel variabel menurut Pearce dan Robinson (2014 : 105-111) pada analisa dengan Porter's five forces.

Tabel 3. Analisis Ancaman Pendatang Baru

\begin{tabular}{|c|c|c|c|}
\hline No & Variabel & Indikator & Bobot Rangking Nilai \\
\hline 1 & Skala ekonomi & & \\
\hline 2 & Diferensiasi produk & & \\
\hline 3 & Biaya pengalihan & & \\
\hline 4 & Kebutuhan modal & & \\
\hline 5 & Kebijakan pemerintah & & \\
\hline
\end{tabular}

Sumber :John A.Pearce II \& Richard B. Robinson Jr, Manajemen Strategis Formulasi Implementasi dan Pengendalian, 2014 :105)

Tabel 4. Analisis Ancaman Produk Pengganti

\begin{tabular}{|c|c|c|c|}
\hline No & Variabel & Indikator & Bobot Rangking Nilai \\
\hline 1 & Produk pengganti & & \\
\hline 2 & Tarif produk pengganti & & \\
\hline 3 & $\begin{array}{l}\text { Pangsa pasar produk } \\
\text { pengganti }\end{array}$ & & \\
\hline
\end{tabular}

Sumber : John A.Pearce II \& Richard B. Robinson Jr, Manajemen Strategis Formulasi Implementasi dan Pengendalian, $2014: 110$

Tabel 5. Analisis Kekuatan Tawar Menawar Pembeli

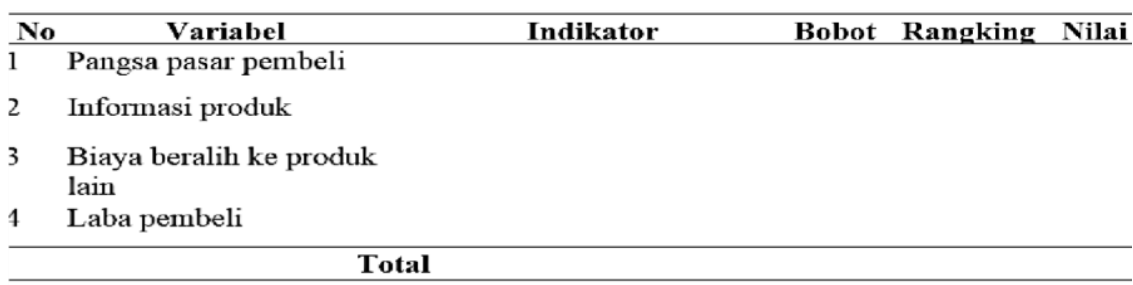

Sumber : John A.Pearce II \& Richard B. Robinson Jr, Manajemen Strategis Formulasi Implementasi dan Pengendalian, 2014 : 109 
Tabel 6. Analisis Kekuatan Tawar Menawar Pemasok

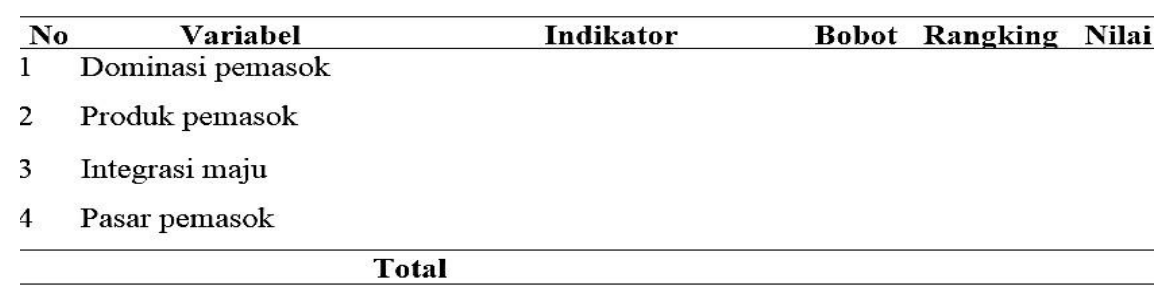

Sumber : John A.Pearce II \& Richard B. Robinson Jr, Manajemen Strategis Formulasi Implementasi dan Pengendalian, $2014: 108$

Tabel 7. Analisis Persaingan Antar Pesaing Industri yang Sama

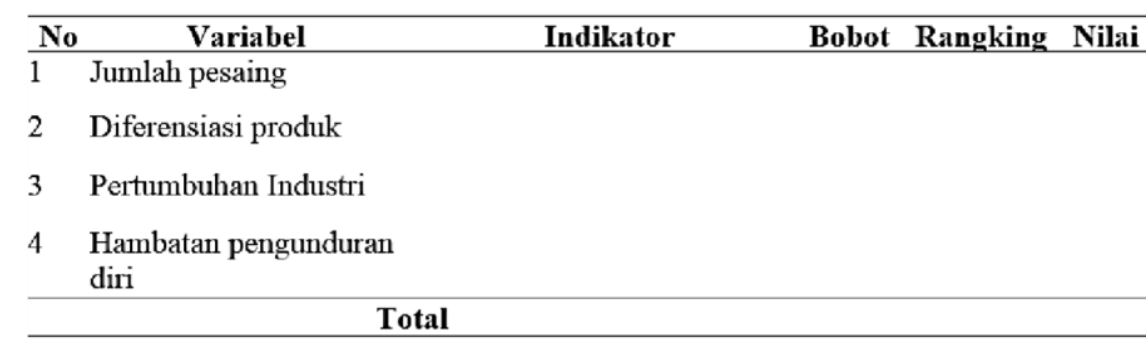

Sumber : John A.Pearce II \& Richard B. Robinson Jr, Manajemen Strategis Formulasi Implementasi dan Pengendalian, $2014: 109$

\section{Analisis SWOT}

\section{Metode Penilaian Analisis SWOT}

Penerapan strategi dalam rangka untuk menjalankan RM. Heni Putri Kaili diperlukan analisa secara internal dan eksternal dengan cara menggunakan alat manajemen yang dikenal dengan analisis SWOT.

Posisi kuadran untuk analisis SWOT dapat dihitung menggunakan kombinasi rating dan bobot, dengan mengumpulkan informasi yang dilakukan melalui kuesioner kemudian dilakukan perhitungan pembobotan berdasarkan hasil pengisian kuesioner untuk kemudian dilakukan analisa lebih lanjut. Untuk membuat rencana strategi berdasarkan kapabilitas internal dan eksternal dilakukan dengan wawancara terkait pengisian kuesioner adalah sebagai berikut:

1. Memilih faktor faktor internal dan eksternal yang telah dianalisa

2. Pemberian peringkat atau rangking dari nilai 1 hingga 4 terhadap masing-masing faktor berdasarkan pada kondisi internal dan eksternal perusahaan tersebut. Cara penilaian adalah sebagai berikut:

1. Nilai 1: Isu yang disampaikan sangat tidak relevan

2. Nilai 2 : Isu yang disampaikan tidak relevan

3. Nilai 3 : Isu yang disampaikan relevan

4. Nilai 4 : Isu yang disampaikan sangat relevan

3. Model yang digunakan untuk menghitung bobot adalah sebagai berikut :

Tabel 8. Bobot SWOT

\begin{aligned} \hline STP & $\begin{array}{l}\text { Sangat tidak penting jika isu sangat tidak mempengaruhi } \\ \text { RM.Heni Putri Kaili }\end{array} \\$\hline TP & $\begin{array}{l}\text { Tidak penting jika isu tidak mempengaruhi RM.Heni } \\ \text { Putri Kaili }\end{array} \\$\hline R & Ragu-ragu jika isu tidak dapat dijustifikasi \\ \hline P & Penting jika isu mempengaruhi RM.Heni Putri Kaili \\ \hline SP & $\begin{array}{l}\text { Sangat Penting jika isu sangat mempengaruhi RM.Heni } \\ \text { Putri Kaili }\end{array}\end{aligned}$

Sumber : Diolah oleh Penulis 
Karena jumlah bobot harus sama dengan 1 (satu) untuk setiap matriks evaluasi, maka bobot untuk setiap narasumber tidak mesti sama, tergantung dari banyak jumlah variabel yang dipilih, atau dapat diformulasikan sebagai berikut:

$$
\mathrm{A}(\mathrm{SP})+\mathrm{B}(\mathrm{P})+\mathrm{C}(\mathrm{R})+\mathrm{D}(\mathrm{TP})+\mathrm{E}(\mathrm{STP})=1.00
$$

Dimana :

$\begin{array}{lll}\mathrm{A} & = & \text { jumlah banyaknya SP dalam satu matrik evaluasi } \\ \mathrm{B} & = & \text { jumlah banyaknya P dalam satu matrik evaluasi } \\ \mathrm{C} & = & \text { jumlah banyaknya R dalam satu matrik evaluasi } \\ \mathrm{D} & = & \text { jumlah banyaknya TP dalam satu matrik evaluasi } \\ \mathrm{E} & = & \text { jumlah banyaknya STP dalam satu matrik evaluasi } \\ \mathrm{SP} & = & \text { bobot nilai Sangat Penting } \\ \mathrm{P} & = & \text { bobot nilai Penting } \\ \mathrm{R} & = & \text { bobot nilai Ragu-ragu } \\ \mathrm{TP} & = & \text { bobot nilai Tidak Penting } \\ \mathrm{STP} & = & \text { bobot nilai Sangat Tidak Penting }\end{array}$

2, sehingga:

Agar Lebih Mudah maka nilai rasio perbandingan antara SP hingga STP, dibuat sama dengan

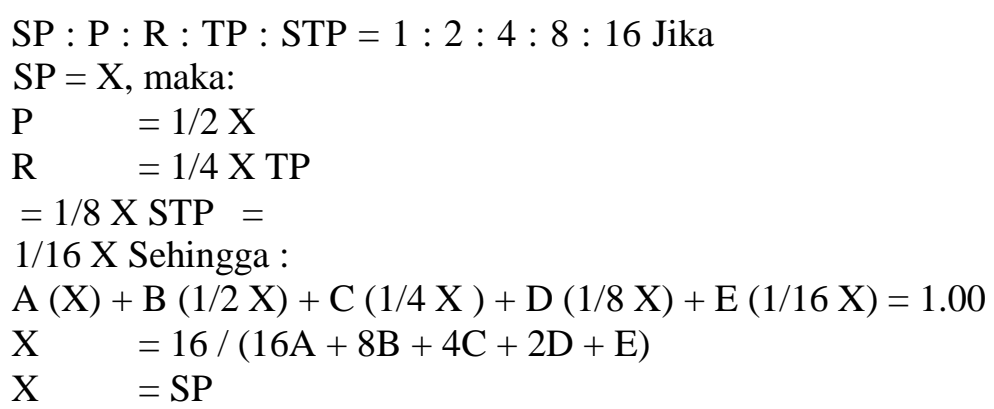

4. Untuk memperoleh nilai faktor tersebut, maka kalikan bobot dengan rangking sehingga akan diperoleh posisi penilaian pada kuadran SWOT.

\section{Model Analisis SWOT}

Analisis SWOT membandingkan antara faktor eksternal peluang dan ancaman dengan faktor internal kekuatan dan kelemahan. Faktor internal dimasukan kedalam matrik yang disebut matrik faktor strategi internal atau IFAS (Internal Strategic Factor Analisis Summary). Faktor eksternal dimasukkan kedalam matrik yang disebut matrik faktor strategi eksternal EFAS (Eksternal Strategic Factor Analisis Summary). Setelah matrik faktor strategi internal dan eksternal selesai disusun, kemudian hasilnya dimasukkan dalam model kuantitatif, yaitu matrik SWOT untuk merumuskan strategi bersaing perusahaan.

Tabel 9. Matrik Faktor Strategi Eksternal (EFAS)

\begin{tabular}{ccccc}
\hline $\begin{array}{c}\text { Faktor Strategi } \\
\text { Eksternal }\end{array}$ & Bobot & Rating & $\begin{array}{c}\text { Bobot } \\
\mathbf{X} \\
\text { rating }\end{array}$ & Keterangan \\
\hline Peluang & $\mathbf{X}$ & $\mathbf{X}$ & $\mathbf{X}$ & \\
Jumlah & $\mathbf{X}$ & $\mathbf{X}$ & $\mathbf{X}$ & \\
Ancaman & $\mathbf{X}$ & $\mathbf{X}$ & $\mathbf{X}$ \\
Jumlah & $\mathbf{X}$ & $\mathbf{X}$ & $\mathbf{X}$ \\
Total & $\mathbf{X}$ & $\mathbf{X}$ & $\mathbf{X}$ & \\
\hline
\end{tabular}


Tabel 10. Matrik Faktor Strategi Internal (IFAS)

\begin{tabular}{ccccc}
\hline $\begin{array}{c}\text { Faktor Strategi } \\
\text { Internal }\end{array}$ & Bobot & Rating & $\begin{array}{c}\text { Bobot } \\
\mathbf{X} \\
\text { rating }\end{array}$ & Keterangan \\
\hline Kekuatan & $\mathbf{X}$ & $\mathbf{X}$ & $\mathbf{X}$ & \\
Jumlah & $\mathbf{X}$ & $\mathbf{X}$ & $\mathbf{X}$ \\
Kelemahan & $\mathbf{X}$ & $\mathbf{X}$ & $\mathbf{X}$ \\
Jumlah & $\mathbf{X}$ & $\mathbf{X}$ & $\mathbf{X}$ \\
Total & $\mathbf{X}$ & $\mathbf{X}$ & $\mathbf{X}$ \\
\hline
\end{tabular}

Sumber : Freddy Rangkuti (2004: 18)

\section{HASIL DAN PEMBAHASAN \\ Analisis Porter Five Forces}

Analisis Porter Five Forces dalam penelitian ini adalah untuk menentukan positioning Rumah Makan Heni Putri Kaili dalam bisnis kuliner di Kota Palu, menganalisis pengaruh lingkungan, potensi bisnis ataupun ancaman, keunggulan kompetitif maupun kelemahan, sehingga diharapkan mampu memberikan arahan bagi perusahan dalam upaya meningkatkan kekuatan, mengantisipasi kelemahan dan menghindarkan perusahan dalam pengambilan kebijakan atau keputusan yang tidak tepat atau salah.

\section{Ancaman pendatang baru (Threat of New Entrants) Skala ekonomi}

Di Kota Palu banyak bermunculan Rumah Makan baru yang merupakan pemain baru dalam bisnis Kuliner di Kota Palu. Diantaranya Kedai Rahmat, Rumah Makan Talise Beach (TABE) dan lain-lain, namun jika dibandingkan rumah makan yang baru memiliki jaringan bisnis yang lebih kecil dibanding RM. Heni Putri Kaili. Sehingga Kedai Rahmat dan Rumah Makan Talise harus mempersiapkan produknya dalam skala yang lebih besar lagi untuk bersaing di dalam industri rumah makan di kota Palu.

\section{Kebutuhan modal}

Pemain baru dalam hal ini Kedai Rahmat dan RM. Talise Beach tentunya membutuhkan modal yang besar untuk bisa bersaing dengan RM. Heni Putri Kaili. Terutama karena dalam bisnis kuliner ini memerlukan modal yang cukup besar untuk mengembangkan usaha rumah makan contohnya untuk menambah fasilitas yang ada, mempromosikan produk dan lain-lain.

\section{Diferensiasi produk}

Diferensiasi produk diketahui bahwa produk yang ditawarkan oleh RM. Talise Beach dan Kedai Rahmat pada industri yang sama tidak memiliki perbedaan yang cukup besar dengan yang ditawarkan oleh RM. Heni Putri Kaili pada saat ini, justru pemain baru akan mengalami hambatan dikarenakan RM. Heni Putri Kaili dalam industri kuliner telah memiliki memiliki fitur yang lebih banyak dibanding rumah makan lainya.

Setelah dianalisis dari informasi di atas, diperoleh hasil analisis bahwa hambatan masuk bisnis ini bagi pendatang baru SEDANG, sesuai dengan hasl analisis pada Tabel 11. 
Tabel 11. Ancaman Pendatang Baru

\begin{tabular}{|c|c|c|c|c|}
\hline \multicolumn{5}{|c|}{ Ancaman Pendatang baru (Threat Of New Entrants) } \\
\hline$\underline{N}_{0}$ & Variabel & $\begin{array}{cc}\text { Indikator } & \text { Bobot } \\
\end{array}$ & nngking & Nilai \\
\hline 1 & Skala Ekonomi & $\begin{array}{l}\text { Layanan yang disiapkan oleh RM. } 0.3 \\
\text { Tabe \& Kedai Rahmat dalam skala } \\
\text { luas (besar) }\end{array}$ & 5 & 1.5 \\
\hline 2 & Kebutuhan Modal & $\begin{array}{l}\text { Kebutuhan modal untuk promosi } 0.3 \\
\text { dan menambah fasilitas yang ada }\end{array}$ & 7 & 2,1 \\
\hline 3 & Diferensiasi Produk & $\begin{array}{l}\text { Produk dari pesaing memiliki } \\
\text { diferensiasi produk }\end{array}$ & 5 & 2,0 \\
\hline & & OTAL & & 5.6 \\
\hline
\end{tabular}

Sumber : Hasil penelitian yang diolah penulis, 2016

\section{Ancaman Produk Pengganti (Threat of Subsitutes)}

\section{Produk pengganti}

Produk pengganti merupakan Rumah Makan/Warung Makan yang menyajikan masakan/produk yang berbeda dengan RM. Heni Putri Kaili adapun beberapa Rumah Makan/Warung Makan yang letak jaraknya tidak jauh dari ialah Warung Bakso Planet \& Coto Maros.

\section{Tarif produk pengganti}

Tarif/Harga yang ditawarkan oleh Warung Bakso Planet \& Coto Maros, relatif lebih murah dan mudah dijangkau oleh seluruh kalangan masyarakat kota Palu.

\section{Pangsa pasar produk pengganti}

Depot SB Mi Ayam Bakso Planet, Rumah Makan Padang Andalas Jl.Raden Saleh \& Coto Maros pada saat ini memiliki pangsa pasar yang cukup besar dikarenakan warung makan tersebut telah memiliki pelanggan tetap dan terus bertambah setiap harinya.

Setelah dianalisis dari informasi data di atas, diperoleh hasil analisis bahwa ancaman produk pengganti diperoleh penilaian yang TINGGI seperti terlihat pada Tabel 12.

Tabel 12. Ancaman Produk Pengganti

\begin{tabular}{|c|c|c|c|c|c|}
\hline \multicolumn{6}{|c|}{ Ancaman Produk Pengganti (Threat of subsitutes) } \\
\hline $\mathrm{N}_{0}$ & Variabel & Indikator & Bobot & Rangking & Nilai \\
\hline 1 & Produk Pengganti & Ada produk pengganti & 0.4 & 6 & 2.4 \\
\hline 2 & $\begin{array}{l}\text { Tarif produk } \\
\text { pengganti }\end{array}$ & $\begin{array}{l}\text { Harga produk pengganti lebih } \\
\text { Murah }\end{array}$ & 0.3 & 5 & 1.5 \\
\hline 3 & $\begin{array}{l}\text { Pangsa pasar } \\
\text { produk pengganti }\end{array}$ & $\begin{array}{l}\text { Produk pengganti } \\
\text { memiliki pasar yang baik }\end{array}$ & 0.3 & 7 & 2.1 \\
\hline \multicolumn{3}{|c|}{ TOTAL } & 1 & & 6.0 \\
\hline
\end{tabular}

Sumber : Hasil penelitian yang diolah penulis, 2016

\section{Kekuatan Tawar Menawar Pembeli (Bargaining Power of Buyers) Pangsa pasar pembeli}

Diketahui bahwa persaingan industri kuliner memiliki pasar yang tinggi dalam hal ini memberikan kekuatan kepada pembeli untuk melakukan tawar menawar pada rumah makan tanpa terkecuali pada RM. Heni Putri Kaili.

\section{Informasi Produk}

Pada umumnya konsumen RM. Heni Putri Kaili adalah wisatawan yang baru pertama kali berkunjung di Kota Palu dan banyak diantaranya belum pernah mencicipi masakan khas kaili. 
Awalnya dari rasa ingin tau konsumen akan masakan khas kaili sehingga mereka akan datang ke RM. Heni Putri Kaili.

\section{Sensivitas Biaya}

Diketahui bahwa konsumen RM. Heni Putri Kaili adalah orang-orang yang tergolong baru sehingga kecil kemungkinan untuk memilih atau menekan biaya seminim mungkin.

Setelah dianalisis dari informasi di atas, diperoleh hasil analisis bahwa Kekuatan tawar menawar diperoleh penilaian yang SEDANG seperti terlihat pada Tabel 13.

Tabel 13. Kekuatan Tawar Menawar Pembeli

\begin{tabular}{|c|c|c|c|c|c|}
\hline \multicolumn{6}{|c|}{ Kekuatan Tawar Menawar Pembeli (Bargaining Power Of Buyers) } \\
\hline No & Variabel & Indikator & Bobc & g & Nilai \\
\hline 1 & Pangsa pasar pembeli & $\begin{array}{l}\text { Pembeli memiliki pangsa pasar } \\
\text { yang sama }\end{array}$ & 0.4 & 5 & 2.0 \\
\hline 2 & Informasi produk & $\begin{array}{l}\text { Pembeli memiliki informasi } \\
\text { produk yang lengkap }\end{array}$ & 0.3 & 4 & 1,2 \\
\hline \multirow[t]{2}{*}{3} & Sensivitas Biaya & $\begin{array}{l}\text { Besarnya biaya yang diterima oleh } \\
\text { pembeli }\end{array}$ & 0.3 & 4 & 1,2 \\
\hline & & OTAL & 1 & & 4,2 \\
\hline
\end{tabular}

Sumber : Hasil penelitian yang diolah penulis, 2016

\section{Kekuatan Tawar Menawar Pemasok (Bargaining Power of Supplier) Dominasi pemasok}

RM. Heni Putri Kaili hanya memiliki 1 pemasok ikan setiap harinya membuat daya tawar sebagai pemasok tersebut menjadi besar.

\section{Produk pemasok}

Kekuatan dari RM. Heni Purti Kaili salah satunya adalah menjamin kualitas dari produk yang akan dijual. Pemasok bahan baku dalam hal ini ikan merupakan salah satu faktor penting bagi RM. Heni Putri Kaili, sehingga pemasok ikan untuk RM. Heni Putri selalu menjamin kualitas produk yang akan didistribusikan.

\section{Integrasi maju}

Dari hasil wawancara yang didapatkan bahwa pemasok ikan RM. Heni Putri kaili tidak memiliki keinginan untuk melakukan pengembangan dalam hal ini integrasi maju.

\section{Pasar pemasok}

Pemasok dapat mempengaruhi RM. Heni Putri Kaili karna pemasok tersebut dapat memperluas cakupan pasarnya tanpa terkecuali pesaing dari RM. Heni Putri Kaili

Setelah dianalisis dari informasi di atas, diperoleh hasil analisis bahwa Kekuatan tawar menawar pemasok diperoleh penilaian yang TINGGI seperti terlihat pada Tabel 14.

Tabel 14. Kekuatan Tawar Menawar Pemasok

\begin{tabular}{|c|c|c|c|c|c|}
\hline \multicolumn{6}{|c|}{ Kekuatan Tawar Menawar Pemasok (Bargaining Power Of Supplier) } \\
\hline No & Variabel & Indikator & Bobot & Rangking & Nilai \\
\hline 1 & Dominasi pemasok & $\begin{array}{l}\text { Pemasok merupakan } \\
\text { kebutuhan pokok Perusahaan }\end{array}$ & 0.3 & 8 & 1,8 \\
\hline 2 & Produk Pemasok & $\begin{array}{l}\text { Produk pemasok berupa produk } \\
\text { Unggulan }\end{array}$ & 0.3 & 8 & 2,4 \\
\hline 3 & Integrasi maju & $\begin{array}{l}\text { Pemasok melakukan integrasi } \\
\text { Maju }\end{array}$ & 0.2 & 2 & 0,4 \\
\hline 4 & Pasar pemasok & memiliki pasar yang & 0.2 & 8 & 1,6 \\
\hline & & TOTAL & 1 & & 6,2 \\
\hline
\end{tabular}

Sumber : Hasil penelitian yang diolah penulis, 2016 


\section{Persaingan antar pesaing yang sama (Rivalry among Competitors) Jumlah pesaing}

Ada beberapa pemain lain yang ikut serta dalam industri Rumah Makan di Kota Palu, menurut BPS Kota Palu jumlah rumah makan dan warung makan di Kota Palu pada akhir tahun 2015 sekitar 85 rumah makan, dan 979 warung makan. Pesaing terdekat RM. Heni Putri Kaili adalah Rumah Makan Kampung Nelayan yang sudah berdiri sejak lama dan menu makanan lebih bervariasi dan Warung Makan Khas Kaili Jalan Tembang yang menyediakan makanan khas kaili yang murah dan memiliki pelanggan tetap setiap harinya.

\section{Diferensiasi produk}

Pemasaran dan fasilitas yang baik merupakan deferensiasi produk yang dimiliki RM. Heni Putri Kaili termasuk dari beberapa pesaing yang menjalankan bisnis kuliner di Kota Palu.

\section{Pertumbuhan industri}

Pertumbuhan bisnis kuliner di Kota Palu pada khususnya mengalami pertumbuhan yang selalu naik tiap tahunnya, sehingga potensi untuk memperoleh tambahan pangsa pasar semakin besar.

\section{Biaya tetap}

Biaya tetap yang harus dikeluarkan industri adalah biaya ketersediaan pengadaan barang, operasional dan maintenance. Penambahan model produk dan produk turunannya yang terintegrasi menyebabkan peningkatan biaya tetap semakin tinggi, jika tidak akan cenderung stabil. Adapun untuk meningkatkan daya tawar terhadap pembeli pada industri ini, penambahan model produk dan layanan memang diperlukan.

\section{Hambatan pengunduran Diri}

Meskipun kompetisi dalam industri ini berpeluang untuk semakin ketat tetapi dengan besarnya peluang akan potensi layanan yang akan meningkat terus, serta perolehan laba yang cukup signifikan. Karena tentunya setiap perusahan ingin tetap menyatakan eksistensinya bahkan akan terus berusaha untuk mengembangkan diri.

Setelah dianalisis dari informasi di atas, diperoleh hasil analisis bahwa Persaingan antar pesaing industri yang sama diperoleh penilaian TINGGI seperti terlihat pada Tabel 15.

Tabel 15. Persaingan Antar Pesaing Industri Yang Sama

\begin{tabular}{|c|c|c|c|c|c|}
\hline \multicolumn{6}{|c|}{ Persaingan antar pesaing industri yang sama (Rivalyy among Competitors) } \\
\hline No & Variabel & Indikator & Bobot & Rangking & Nilai \\
\hline 1 & Jumlah pesaing & Pesaing yang beragam & 0.3 & 7 & 2,1 \\
\hline 2 & Diferensiasi produk & Antar produk hanya ada sedikit & 0.1 & 8 & 0.8 \\
\hline 3 & Pertumbuhan industri & $\begin{array}{l}\text { Pertumbuhan industri yang } \\
\text { Cepat }\end{array}$ & 0.3 & 7 & 2.1 \\
\hline 4 & Biaya tetap & Biaya tetap yang tinggi & 0.2 & 6 & 1.2 \\
\hline 5 & $\begin{array}{l}\text { Hambatan } \\
\text { pengunduran }\end{array}$ & $\begin{array}{l}\text { Hambatan pengunduran } \\
\text { diri yang tinggi }\end{array}$ & 0.1 & 5 & 0.5 \\
\hline \multicolumn{3}{|r|}{ TOTAL } & 1 & & 6,7 \\
\hline
\end{tabular}

Sumber : Hasil penelitian yang diolah penulis, 2016

Setelah dianalisis satu persatu dari 5 pengaruh yang mempengaruhi RM. Heni Putri Kaili ini dapat digambarkan pada Gambar 2 untuk memudahkan dalam pembacaan hasil keseluruhan Porter 5 Forces. 


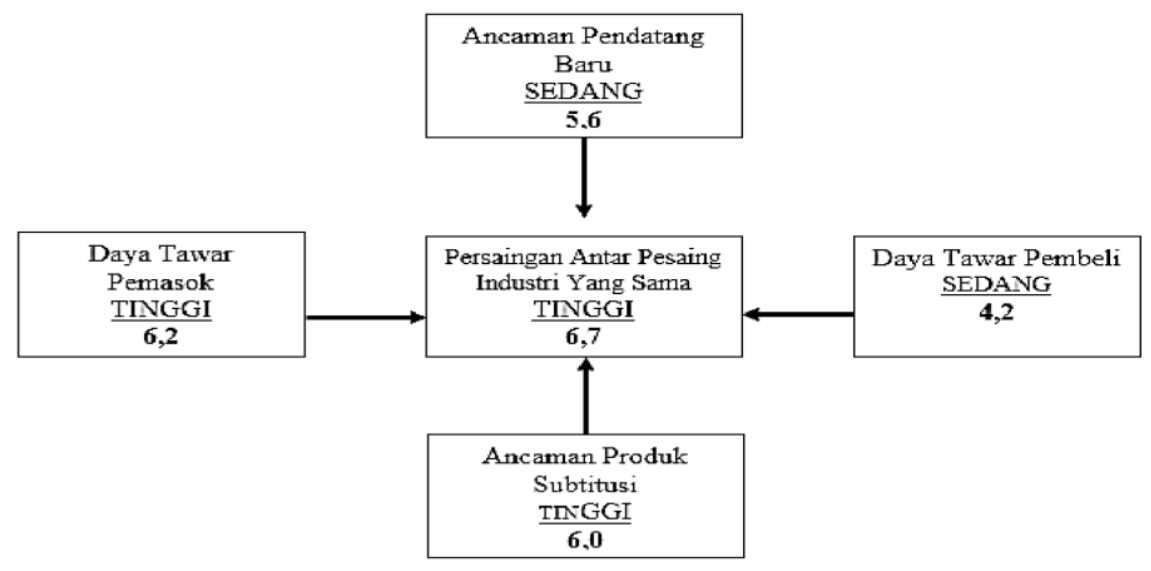

Gambar 2. Hasil Analisis Porter Five Forces

Dari keseluruhan hasil analisis tersebut, diperoleh hasil analisis berdasarkan penilaian dan parameter sebagai berikut dibawah ini:

1. Persaingan Antar Pesaing Dalam Industri Sama, merupakan posisi yang tertinggi dengan nilai 6,7, karena persaingan pada bisnis ini dapat mengurangi pendapatan atau omzet dari RM. Heni Putri Kaili.

2. Daya Tawar Pemasok, memperoleh hasil TINGGI dengan nilai 6,2, karena Rm. Heni Putri Kaili memiliki keteragantungan bahan baku yang sangat tinggi terhadap produk pemasok.

3. Ancaman Produk Pengganti, memperoleh hasil yang TINGGI dengan nilai 6,0, dimana produk pengganti dalam hal ini Depot SB Mi Ayam Bakso Planet, Rumah Makan Padang Andalas Jl. Raden Saleh \& Coto Maros yang letaknya tidak jauh dari RM, Heni Putri Kaili akan mengancam dengan pengaruh ancaman yang besar, sehingga RM. Heni Putri Kaili memerlukan strategi yang baik untuk menghadapi ancaman terhadap produk pengganti seperti rumah makan/warung makan yang menyediakan menu masakan non kaili atau dari luar kota Palu.

4. Ancaman Terhadap Pendatang Baru, memperoleh hasil yang SEDANG dengan nilai 5,6, ancaman pendatang baru akan mengalami sedikit hambatan sehingga pemain baru dalam hal ini RM. Talise Beach (TABE) dan Kedai Rahmat akan mengalami kesulitan.

5. Daya Tawar Pembeli, memperoleh hasil penilaian SEDANG dengan nilai 4,2, karena diketahui bahwa konsumen RM. Heni Putri Kaili adalah orang - orang yang tergolong baru sehingga kecil kemungkinan untuk melakukan daya tawar yang tinggi.

Dengan melihat hasil analisis Porter Five Forces di atas, dapat disimpulkan bahwa kondisi persaingan Rumah Makan Heni Putri Kaili pada industri rumah makan di Kota Palu mengalami Persaingan yang Tinggi. Sehingga RM. Heni Putri Kaili harus memiliki strategi bersaing yang tepat untuk mengatasi masalah-masalah tersebut.

\section{Analisis SWOT}

Proses analisis SWOT dilakukan untuk menguji sifat permintaan dan tekanan pihak eksternal, mengidentifikasi peluang dan kendala, sumber daya dan menilai kapasitas internal. Hasil Penilaian SWOT mengarahkan RM. Heni Putri Kaili dalam pengembangan strategi untuk membangun kekuatan, mengatasi kelemahan, menangkal ancaman, dan mengeksploitasi peluang. Analisis SWOT memberikan informasi yang berguna untuk menyelaraskan sumber daya dan kemampuan dengan lingkungan yang kompetitif terhadap perusahaan. Model ini dapat digunakan untuk menentukan strategi dan berlaku juga untuk semua situasi membuat keputusan. Berikut definisi masing- masing elemen SWOT:

A. Strength; penilaian terhadap kekuatan internal diandingkan dengan pesaing lainnya dapat diindikasikan sebagai berikut :

1. Pengawasan Mutu yang ketat

2. Menu yang disajikan memiliki cita rasa yang khas dan berbeda

3. Fasilitas yang lengkap 
4. Suasana rumah makan yang menarik dan nyaman

5. Melakukan promosi secara aktif

B. Weakness; adalah faktor internal mengenai kelemahan yang terkait dengan manajemen bisnis di Rumah Makan Heni Putri Kaili dan merupakan lawan dari kekuatan perusahaan tersebut. Adapun faktor kelemahan adalah sebagai berikut:

1. Pemberian harga produk kurang kompetitif'

2. Belum memiliki cabang untuk memperluas pangsa pasar

3. Pemasok bahan baku yang dimiliki masih kurang

4. Produk tidak tahan lama

C. Opportunities; merupakan peluang-peluang yang dapat dibuat atau diperoleh perusahaan untuk tetap mengembangkan dan mempertahankan bisnis berdasarkan kemampuan. Adapun peluang peluang yang dapat diperoleh dan diciptakan adalah sebagai berikut:

1. Petumbuhan penduduk meningkat

2. Berada di pusat lokasi wisata kota Palu

3. Sering diadakan kegiatan nasional dan internasional di Kota Palu

D. Threads; ancaman yang muncul bagi internal perusahaan dan lingkungan industri. Adapun ancaman - ancaman yang ada adalah sebagai berikut:

1. Ancaman masuknya pemain baru

2. Banyaknya produk pengganti

3. Harga bahan baku tidak stabil

\section{Analisis Faktor Internal dan Eksternal Menggunakan IFAS dan EFAS}

Tahap-tahap dalam menyusun tabel Internal Factor Analysis Summary (IFAS) dan Eksternal Factor Analysis Summary (EFAS) dengan menentukan faktor-faktor yang menjadi Strength dan Weakness Rumah Makan Heni Putri kaili, selanjutnya memberikan bobot masingmasing faktor dari skala mulai dari 0,0 (tidak penting) sampai dengan 1,0 (sangat penting) dimana semua bobot tersebut jumlahnya tidak melebihi skor total 1,00. Menghitung rating untuk masing-masing faktor dengan memberikan skala mulai dari 1 (dibawah rata-rata) sampai dengan 4 (sangat baik). Nilai taring Strength dan Weakness selalu bertolak belakang, begitu juga dengan Opportunity dan Threat. Hasil analisis dari IFAS dan EFAS dapat dilihat pada Tabel 16 dan 17.

Tabel 16. Matrik IFAS Rumah Makan Heni Putri Kaili

\begin{tabular}{|c|c|c|c|}
\hline $\begin{array}{c}\text { Faktor-Faktor Strategis } \\
\text { Internal } \\
\end{array}$ & Bobot & Rating & Skor \\
\hline \multicolumn{4}{|l|}{ Strengths (S): } \\
\hline - Pengawasan Mutu yang ketat & 0.1 & 4 & 0.4 \\
\hline $\begin{array}{l}\text { - Menu yang disajikan memiliki cita rasa yang } \\
\text { khas dan berbeda }\end{array}$ & 0.13 & 4 & 0.52 \\
\hline - Fasilitas yang lengkap & 0.20 & 3 & 0.6 \\
\hline $\begin{array}{l}\text { - Suasana rumah makan yang menarik dan } \\
\text { nyaman }\end{array}$ & 0.15 & 4 & 0,6 \\
\hline - Melakukan promosi secara aktif & 0.05 & 4 & 0.2 \\
\hline Sub Total & & & 2,32 \\
\hline \multicolumn{4}{|l|}{ Weaknesses $(\mathbf{K})$} \\
\hline - Pemberian harga produk kurang kompetitif & 0.05 & 1 & 0,05 \\
\hline $\begin{array}{l}\text { - Belum memiliki cabang untuk memperluas } \\
\text { pangsa pasar }\end{array}$ & 0.07 & 2 & 0,14 \\
\hline $\begin{array}{l}\text { Pemasok bahan baku (ikan) yang dimiliki } \\
\text { masih kurang }\end{array}$ & 0.20 & 3 & 0,6 \\
\hline - Produk tidak tahan lama & 0.05 & 2 & 0,1 \\
\hline $\begin{array}{l}\text { Sub Total } \\
\text { Total }\end{array}$ & 1.00 & & $\begin{array}{l}0,89 \\
3,21\end{array}$ \\
\hline
\end{tabular}

Sumber : Hasil penelitian yang diolah penulis, 2016

Dari hasil analisis IFAS pada Tabel 16, faktor Strength mempunyai total nilai skor 2,32 sedangkan Weakness mempunyai total nilai skor 0,89 .

Seperti halnya pada $I F A S$, maka pada faktor-faktor strategis eksternal EFAS juga dilakukan identifikasi yang hasilnya pada Tabel 17. 
Tabel 17. Matrik EFAS Rumah Makan Heni Putri Kaili

\begin{tabular}{|c|c|c|c|}
\hline $\begin{array}{c}\text { Faktor-Faktor Strategis } \\
\text { Eksternal }\end{array}$ & Bobot & Rating & Skor \\
\hline $\begin{array}{l}\text { Opportunities (O) : } \\
\text { - Petumbuhan penduduk meningkat } \\
\text { - Berada di pusat lokasi wisata kota Palu } \\
\text { - Sering diadakan kegiatan nasional dan } \\
\text { internasional di Kota Palu }\end{array}$ & $\begin{array}{l}0.10 \\
0.20 \\
0.15\end{array}$ & $\begin{array}{l}2 \\
4 \\
3\end{array}$ & $\begin{array}{l}0.20 \\
0,80 \\
0,45\end{array}$ \\
\hline $\begin{array}{cc}\text { Sub Total } & 0.45 \\
\end{array}$ & & & 1.45 \\
\hline $\begin{array}{l}\text { Threads (T) } \\
\text { - Ancaman masuknya pemain baru } \\
\text { - Banyaknya produk pengganti } \\
\text { - Kurangnya penikmat masakan tradisonal } \\
\text { - Harga bahan baku tidak stabil }\end{array}$ & $\begin{array}{l}0.10 \\
0.25 \\
0.10 \\
0.10\end{array}$ & $\begin{array}{l}4 \\
4\end{array}$ & $\begin{array}{l}0.60 \\
1 \\
0.30 \\
0.40\end{array}$ \\
\hline $\begin{array}{l}\text { Sub Total } \\
\text { Total }\end{array}$ & 1.00 & & $\begin{array}{l}2,30 \\
3,75 \\
\end{array}$ \\
\hline
\end{tabular}

Sumber : Hasil penelitian yang diolah penulis, 2016

Analisis Tabel 17, menunjukkan bahwa untuk faktor-faktor Opportunities nilai skornya 1,45. dan faktor Threads 2,30. Selanjutnya, nilai total skor dari masing-masing faktor dapat dirinci:

1. Faktor kekuatan (Strengths) : 2,32 2.

2. Faktor kelemahan (Weaknesses) : 0,89

3. Faktor peluang (Opportunities) $: 1.454$.

4. Faktor ancaman (Threats) $\quad: 2,30$

Maka diketahui nilai Strengths diatas nilai Weakness selisih (+) 1,43 dan nilai Opportunities dibawah nilai Threads selisih (-) 0,85 .

Dari hasil identifikasi faktor-faktor tersebut maka dapat digambarkan dalam Diagram SWOT, dapat dilihat pada Gambar 3.

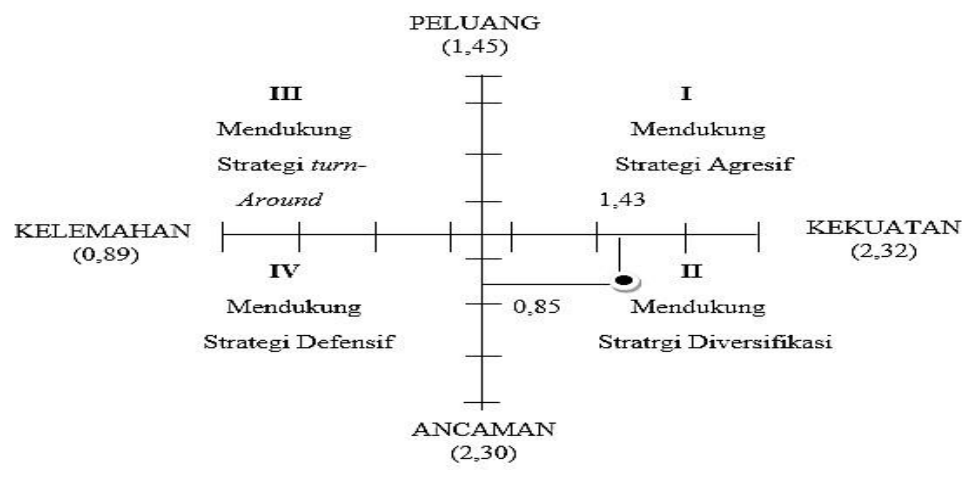

Gambar 3. Diagram SWOT

Dari nilai total masing-masing faktor selain digambarkan dalam diagram SWOT juga dapat digambarkan dalam rumusan matrik SWOT sebagai berikut:

Tabel 18. Rumusan Kombinasi Strategi Matrik SWOT

\begin{tabular}{|c|c|c|}
\hline EFAS IFAS & Strength (S) & Weakness (W) \\
\hline Opportunity (O) & $\begin{array}{l}\text { Strategi (SO): } \\
=2,32+1,45 \\
=3,77\end{array}$ & $\begin{array}{l}\text { Strategi (WO) : } \\
=0,89+1,45 \\
=2.34\end{array}$ \\
\hline Threat (T) & $\begin{array}{l}\text { Strategi (ST): } \\
=2,32+2,30 \\
=4,62\end{array}$ & $\begin{array}{l}\text { Strategi (WT) : } \\
=0,89+2,30 \\
=3,16\end{array}$ \\
\hline
\end{tabular}

Sumber : Hasil penelitian yang diolah penulis, 2016 


\section{Matrik SWOT}

Dari analisis matrik IFAS dan EFAS pada tabel di atas, telah disusun pula matrik SWOT untuk menganalisis rumusan alternatif strategi SO, WO, ST dan WT yang hasil analisisnya seperti pada Tabel 19.

Tabel 19. Matrik SWOT RM. Heni Putri Kaili

\begin{tabular}{|c|c|c|}
\hline EFAS & $\begin{array}{l}\text { Strength }(\mathrm{S}) \\
\text { 1. Pengawasan Mutu yang } \\
\text { ketat } \\
\text { 2. Menu yang disajikan } \\
\text { memiliki cita rasa yang } \\
\text { khas dan berbeda } \\
\text { 3. Fasilitas yang lengkap } \\
\text { 4. Suasana rumah makan } \\
\text { yang menarik \& nyaman } \\
\text { 5. Melakukan promosi } \\
\text { secara aktif }\end{array}$ & $\begin{array}{l}\text { Weaknesses (W) } \\
\text { 1. Pemberian harga produk } \\
\text { kurang kompetitif } \\
\text { 2. Belum memiliki cabang } \\
\text { untuk memperluas pangsa } \\
\text { pasar }\end{array}$ \\
\hline $\begin{array}{l}\text { Opportunities }(\mathrm{O}) \\
\text { 1. Petumbuhan penduduk } \\
\text { meningkat } \\
\text { 2. Berada di pusat lokasi } \\
\text { wisata kota Palu } \\
\text { 3. Sering diadakan } \\
\text { kegiatan nasional dan } \\
\text { internasional di Kota } \\
\text { Palu }\end{array}$ & $\begin{array}{l}\text { Strategi SO } \\
\text { - Menjalin hubungan kerja } \\
\text { sama dengan Dinas } \\
\text { Pariwisata dan ekonomi } \\
\text { kreatif kota Palu. } \\
\text { (S2,S3,S4,S5,O2,O3) } \\
\text { Membuka jam kerja } \\
\text { lebih awal di hari } \\
\text { minggu/libur } \\
\text { (S2,S3,S4,O2,O3) }\end{array}$ & $\begin{array}{l}\text { - Strategi WO } \\
\text { Membuka cabang untuk } \\
\text { memperluas pangsa pasar } \\
\text { (W2,O1,O2,O3) } \\
\text { - Melakukan promosi } \\
\text { produk, melalui cara Paket } \\
\text { menarik dan murah } \\
\text { (W1,O1,O2,O3) }\end{array}$ \\
\hline $\begin{array}{l}\text { Threats (T) } \\
\text { 1. Ancaman masuknya } \\
\text { pemain baru } \\
\text { 2. Banyaknya produk } \\
\text { pengganti (Warung } \\
\text { Makan) } \\
\text { 3. Harga bahan baku tidak } \\
\text { stabil }\end{array}$ & $\begin{array}{l}\text { Strategi ST } \\
\text { 1) Mempertahankan serta } \\
\text { meningkatkan pelayanan } \\
\text { (S1,S3,S4,T1,T2,T3) } \\
\text { - Meningkatkan promosi } \\
\text { produk unggulan tanpa } \\
\text { melupakan produk - } \\
\text { produk yang belum } \\
\text { dikenal luas dipasaran } \\
\text { (S5,T1,T2,T3,T4) }\end{array}$ & $\begin{array}{l}\text { Strategi WT } \\
\text { - Menjalin kerja sama yang } \\
\text { baik dengan pemasok dan } \\
\text { menambah kuantitas } \\
\text { pemasok } \\
\text { (W3,T1,T4) } \\
\text { Tetap menjaga \& } \\
\text { meningkatkan kualitas } \\
\text { Produk dalam bentuk nasi } \\
\text { dos, prasmanan, d11 } \\
\text { (W4,T1,T2,T3) }\end{array}$ \\
\hline
\end{tabular}

\section{Sumber : Hasil penelitian yang diolah penulis, 2016}

\section{Strategi Berdasarkan Hasil Analisis SWOT}

Berdasarkan Gambar 3 hasil dari evaluasi dan terpetakan pada kuadran ST (strenghts \& threaths) makan untuk selanjutnya strategi akan berfokus kepada strategi ST dimana strategi ST yang telah disebutkan pada Tabel 19 akan melakukan Strategi menggunakan kekuatan untuk mengatasi ancaman yang dihadapi dengan cara Strategi Diversifikasi (produk/pasar) dengan program strategi sebagai berikut :

\section{Mempertahankan Serta Meningkatkan Pelayanan}

RM. Heni Putri Kaili sudah memiliki kekuatan pada suasana tempat yang tidak dimiliki oleh para pesaing, suasana RM. Heni Putri Kaili membuat konsumen nyaman berlama-lama menikmati menu yang disajikan sehingga perlu dipertahankan untuk mengatasi pesaing - pesaing dari pendatang baru maupun yang sudah lama dalam industri rumah makan di kota Palu serta perlu adanya peningkatan pada jenis pelayanan lainya seperti cepatnya menu yang disajikan kepada konsumen.

\section{Meningkatkan promosi produk unggulan tanpa melupakan produk - produk yang belum dikenal luas dipasaran}

Rumah Makan Heni Putri Kaili sudah cukup terkenal dengan terdapatnya Papan Promosi dibeberapa sudut jalan kota Palu dan iklan di koran-koran lokal, akan tetapi promosi tersebut tidaklah cukup untuk menghadapi persaingan industri rumah makan yang ketat di Kota Palu, pertumbuhan Rumah makan \& meningkat setiap tahunya mewajibkan RM. Heni Putri Kaili melakuan promosi dengan berbagai cara seperti :

1. Pemberian harga yang kompetitif

2. Pemberian harga discount atau gratis konsumen untuk yang berulang tahun 
3. Bekerja sama dengan instansi pemerintahan atau perusahaaan untuk melakukan cathering setiap hari.

4. Melakukan promosi setiap hari di Sosial Media (Instagram, Facebook, Twitter, Youtube, dll)

5. Melakukan Delivery Order

\section{KESIMPULAN DAN SARAN}

\section{Kesimpulan}

Menggunakan analisis Porter Five Forces, diperoleh hasil analisis berdasarkan parameter sebagai berikut dibawah ini :

1. Persaingan Antar Pesaing Dalam Industri Sama, merupakan posisi yang tertinggi dengan nilai 6,7, karena persaingan pada bisnis ini dapat mengurangi pendapatan atau omzet dari RM. Heni Putri Kaili.

2. Daya Tawar Pemasok, memperoleh hasil TINGGI dengan nilai 6,2, karena RM. Heni Putri Kaili memiliki keteragantungan bahan baku yang sangat tinggi terhadap produk pemasok.

3. Ancaman Produk Pengganti, memperoleh hasil yang TINGGI dengan nilai 6,0, dimana produk pengganti dalam hal ini Depot SB Mi Ayam Bakso Planet, Rumah Makan Padang Andalas Jl. Raden Saleh \& Coto Maros yang letaknya tidak jauh dari RM, Heni Putri Kaili akan mengancam dengan pengaruh ancaman yang besar, sehingga RM. Heni Putri Kaili memerlukan strategi yang baik untuk menghadapi ancaman terhadap produk pengganti seperti rumah makan/warung makan yang menyediakan menu masakan non kaili atau dari luar kota Palu.

4. Ancaman Terhadap Pendatang Baru, memperoleh hasil yang SEDANG dengan nilai 5,6, ancaman pendatang baru akan mengalami sedikit hambatan sehingga pemain baru dalam hal ini RM. Talise Beach dan Kedai Rahmat akan mengalami kesulitan.

5. Daya Tawar Pembeli, memperoleh hasil penilaian SEDANG dengan nilai 4,2, karena diketahui bahwa konsumen RM. Heni Putri Kaili adalah orang - orang yang tergolong baru sehingga kecil kemungkinan untuk melakukan daya tawar yang tinggi.

Dengan melihat hasil analisis Porter Five Forces di atas, dapat disimpulkan bahwa kondisi persaingan Rumah Makan Heni Putri Kaili pada industri rumah makan di Kota Palu mengalami Persaingan yang Tinggi. Sehingga RM. Heni Putri Kaili harus memiliki strategi bersaing yang tepat untuk mengatasi masalah - masalah tersebut.

Menggunakan analisis SWOT, menunjukkan bahwa internal strategic factor analysis summary (IFAS), hasil faktor Kekuatan Rm. Heni Putri Kaili memiliki skor 2,32 dan faktor kekuatan Kelemahan memiliki skor 0,89 sehingga memiliki total skor 3,21 sedangkan external strategic factor analysis summary (EFAS), Hasil faktor peluang Rm. Heni Putri Kaili memiliki skor 1,45 dan ancaman memiliki skor 2,30 sehingga memiliki total skor 3,75 dari hasil tersebut diagram SWOT pada Rumah Makan Heni Putri Kaili berada pada posisi kuadran 2 (Dua) yaitu strategi ST.

\section{Saran}

Berdasarkan pada analisis dan kesimpulan yang berkaitan dengan penelitian ini, maka saransaran yang dapat diajukan adalah :

1. Sebaiknya pemilik RM. Heni Putri Kaili membuat laporan setiap periode pertriwulan/pertahun tentang kekuatan, kelemahan, peluang dan ancaman yang harus dimonitor dan dimengerti jika, sehingga lebih cepat mengatasi ancaman pesain serta perkembangan - perkembangan yang terjadi terutama dalam persaingan pasar.

2. Sebagai strategi untuk peningkatan dan mempertahankan posisi RM. Heni Putri Kaili terhadap para pesaing, pengembangan terhadap tempat dan jenis menu makanan dan minuman maupun promosi produk yang baru wajib dilakukan RM. Heni Putri Kaili sehingga konsumen lebih tertarik dan lebih loyal.

3. Strategi yang harus diterapkan Rumah Makan Heni Putri Kaili adalah menggunakan kekuatan untuk mengatasi ancaman yang dihadapi dengan cara Strategi Diversifikasi (produk/pasar).

\section{REFERENSI}

Badan Pusat Statistik Daerah Palu. (2015)/ Indikator Kependudukan di Kota Palu tahun 2013 - 2015: diperoleh pada 03 Maret 2016. 
Husein, U. (1999). Riset Strategi Perusahaan, Jakarta: PT. Alex Media Computindo

Pearce II, J. A. \& Junior, R. B. R. ( 2014). Manajemen Strategis Formulasi Implementasi dan Pengendalian, Jakarta: Salemba Empat.

Porter, M. E. (2006). Strategi Bersaing Teknik Menganalisis Industri dan Pesaing, Alih Bahasa : Agus Maulana, Jakarta : Erlangga.

Rangkuti, F. (2004). Analisis SWOT Teknik Membedah Kasus Bisnis. Jakarta: PT. Gramedia Pustaka Utama.

Robert \& K. Yin (1999). Case Study Research.

Sarwono, J. (2006). Metodologi Penelitian Kualitatif \& Kuantitatif, Yogyakarta: Graha Ilmu.

Satori, D. \& Komariah, A. (2014). Metodologi Penelitian Kualitati., Bandung : Alfabeta. 